Dialectologia 16 (2016), 71-91.

ISSN: 2013-2247

Received 25 June 2014.

Accepted 10 June 2015.

\title{
THE SOCIOLINGUISTIC VARIATION OF PALATALIZATION: THE CASE OF GERNIKA-LUMO ${ }^{1}$
}

\author{
Ariane EnsunZa AldamizetXebarRIA \\ Universidad del País Vasco/EHU* \\ ariane.ensunza@ehu.com
}

\section{Abstract}

It is a long time since dialectal researches have taken a new course, focused on urban spoken varieties more than on rural varieties. Moreover, they focus on the interaction between independent variables and linguistic variables. Nevertheless, this is not the case of the Basque language, as there have been few researches from this point of view.

The aim of this contribution is to show that Basque is not an isolated case; as a living language it has changed through time and it is, indeed, changing nowadays. The focus of the research is the variant of the basque spoken in Gernika, and it is based in 5 linguistic variables which present a sociolinguistic variation of palatalization: variable (is), variable (it), variable (il), variables (ind) and (ild) and variable (i_V). The realizations of these variables have been studied taking into account some independent variables such as age, genre, parent's origin and school.

\section{Keywords}

language change, sociolinguistic variation, variationist sociolinguistic, palatalization, Basque

\section{VARIACIÓN SOCIOLINGÜÍSTICA DE LA PALATALIZACIÓN: \\ EL CASO DE GUERNICA Y LUNO}

\section{Resumen}

Hace tiempo que las investigaciones dialectales tomaron una nueva dirección, focalizándose más en las variedades habladas en zonas urbanas que en las rurales. En este nuevo rumbo, las nuevas

\footnotetext{
${ }^{1}$ This article was presented in ICLaVE VII in Trondheim and it was part of a wider investigation, which is going to be published soon in ASJU 2012. All this researches were possible thanks to an investigation program of The Basque Government called Ikertzaileak prestatzeko eta hobetzeko laguntzen programa (kod. BFI-2010-253).

*Facultad de Letras. Paseo de la Universidad no 5. 01006 Vitoria-Gasteiz. (Alava)
} 
investigaciones dialectales se centran en la interacción que hay entre las variables independientes y las variables lingüísticas. Aun así, esto no ocurre con el vasco, ya que han sido escasas las investigaciones realizadas desde esta perspectiva.

Por lo tanto, la finalidad de esta contribución es exponer que el vasco no es un caso excepcional ya que como lengua viva ha ido cambiando durante el tiempo y, de la misma forma, continúa cambiando en la actualidad. El foco de la investigación es la variedad del vasco hablado en la localidad de Guernica y Luno, y está basado en 5 variables lingüísticas que presentan variación sociolingüística de la palatalización: variable (is), variable (it), variable (il), variables (ind) y (ild) y variable (i_V). La realización de estas variables ha sido estudiada teniendo en cuenta las variables independientes de edad, genero, origen de los padres y escuela en la que han estudiado.

\section{Palabras clave}

cambio lingüístico, variación sociolingüística, sociolingüística variacionista, palatalización, vasco

Changes typically begin with variation, with alternative ways of saying the same thing entering the language.

Campbell ([1998] 2004: 219)

\section{Introduction}

"One of the fundamental things you need to understand about languages is that they are always changing" wrote Trask \& Millar in 2007: 1) and nowadays it is a universally accepted axiom. Furthermore, it is said that language change is not due to its decay, but to sate its daily needs. That is why it is so interesting and important to study languages in their day to day variation. Nevertheless, it seems that some Basque linguists have forgotten that language and their dialects or variants, are not static and eternal, but they are in constant and uninterrupted change. Or, in other cases, language change is only seen as a historical event so only the differentiation between two historical stages is researched. Fortunately, it is not the case of, for example, the EUDIA dialectal researcher group, which constantly has been studying the variation happening on the whole geographical area of Basque and the sociolinguistic variation between two generations (Aurrekoetxea 2008; Ormaetxea 2011; Santazilia 2010; Unamuno 2010; etc. But there have been other researchers too: Garmendia 2008; Gaminde 2003, 2009, 
2010a, 2010b; Gaminde \& Zubillaga 2010; Gaminde \& Romero 2011; Gaminde et al. 2012; Amorrortu 2003; Ezenarro 2008; Lujanbio 2011; Ensunza 2014; etc.).

On the other hand, it has been a long time since the international dialectal researches took a new course focused on urban spoken varieties more than on rural varieties. Moreover, it is focused on the interaction between independent variables and linguistic variables. Nonetheless, this is not either the case of the Basque language, since there have been few researches made from this point of view.

Nonetheless, nowadays there is no doubt that dialects and variants are result of previous stages, that's it, one language stage is the consequence of a previous language stage (Mitxelena 1981: 518). So it is crucial to research where does the Basque spoken in Gernika have its background and in which direction is changing. But that is a task for the future, because if a typology of diachronic change wants to be done, we ought to have a previous knowledge of the typology of synchronic change due to the fact that every diachronic change starts as a synchronic variation.

The aim of this contribution is to show that Basque is not an isolated case in the world; as a living language it has changed through time and it is, indeed, changing nowadays. As Tagliamonte (2012: 2) said:

\footnotetext{
Variation in language can be observed just about everywhere from a conversation you overhear on the street to a story you read in the newspaper. Sociolinguists notice such variations too. In undertaking sustained analysis, what they discover is that people will use one form and then another for more or less the same meaning all the time the language varies. The harder part is to find the order, or the system, in the variation chaos.
}

Moreover, everybody notices that in one's hometown not everybody speaks in the same way, adults use forms, pronunciations, words or expressions that young generations do not, and vice versa. In fact, the speaker of a community is the one who realizes that young and adults do not speak exactly the same. The key is to find which the logic of such variation is. So, what causes the variation? Do changes occur in a specific group or are they sporadic? Do the speakers make changes consciously or 
unconsciously? But as Trask \& Millar (2007: 14) pointed out, there is not a simple answer to explain the variation because the reasons for change are many and varied and, nowadays, only few of them are well known, such as fashion. Nevertheless, it cannot be said that the only and unique reason for variation is fashion, since at least after Labov's multiple works (1963, 1966, 1972a, 1972b, 1981, 1994, 2001, 2010, etc.), it is common knowledge that there are both internal factors and external factors that cause language variation.

That variation can be studied in three ways: diatopically (according to the geography), diastratically (by social factors) and diafasically (in accordance with the register). In the case of Basque, in the last years there have been many researches that studied geographycal variation, so they have analyzed de linguistic differentiation from town to town more than the variation that can be in each locality (Aurrekoetxea 1995; Gaminde 1984a, 1984b, 1985, 2003; Zuazo 1998, 2003, 2008; Camino 2003; Zelaieta 2008). On the other hand, the studies that have been done in a certain locality have continued the way of the traditional dialectology, so they have analyzed the Basque of the most adult generations (Ormaetxea 2002; Makazaga 2010). Moreover, most of the researches that have analyzed the variation of Basque have described the variants of each locality as if the whole community would speak in the same way, that's it, the most common then when describing a local variant was to give one and just one form. That is why we do know so little about the variation of the local variants of Basque, while in other languages (mainly in English) it is a while since special progress was made in this field. The aim of this contribution is not, in any case, to rest importance to those researches, but bring some soil to fill the hole.

Therefore, we have researched the variant of the Basque spoken in the locality of Gernika focusing on some linguistic variables, all of them phonetic, which nowadays are fluctuating. Those linguistic variables have been analyzed taking into account some social factors such as age, genre, parent's origin and the school where they have studied. As this kind of sociolinguistic researches claim, language is inevitably associated with a speaker and as that speaker is part of the community, language can not be separated from its sociolinguistic context. That's why before going any further, we have 
consider crucial to point out some characteristics about Gernika, so that we can understand better the community in which our research is based on.

\section{Locating Gernika}

As the following maps shows, geographically Gernika is located in the northcentral part of Bizkaia, very close to our capital Bilbao. It is set in the region called Busturialdea and in the end of the biosphere of Urdaibai. The river Oka runs through it dividing Busturialdea in two: those towns which stand in the left bank of the river and those which stand in the right bank:

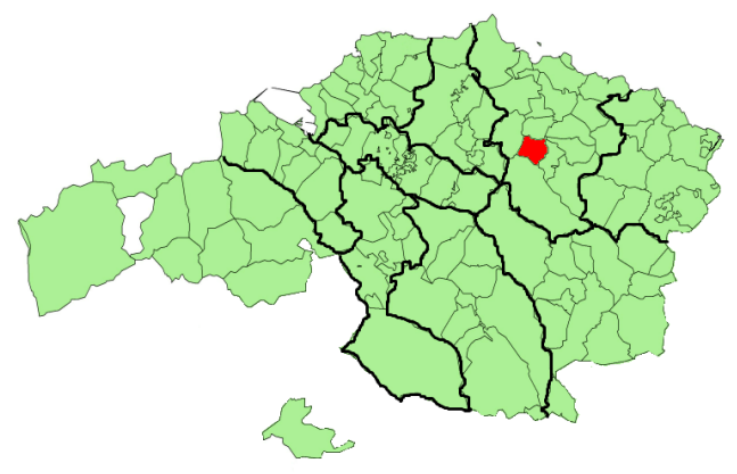

Map 1: Location of Gernika in Bizkaia and Busturialdea.

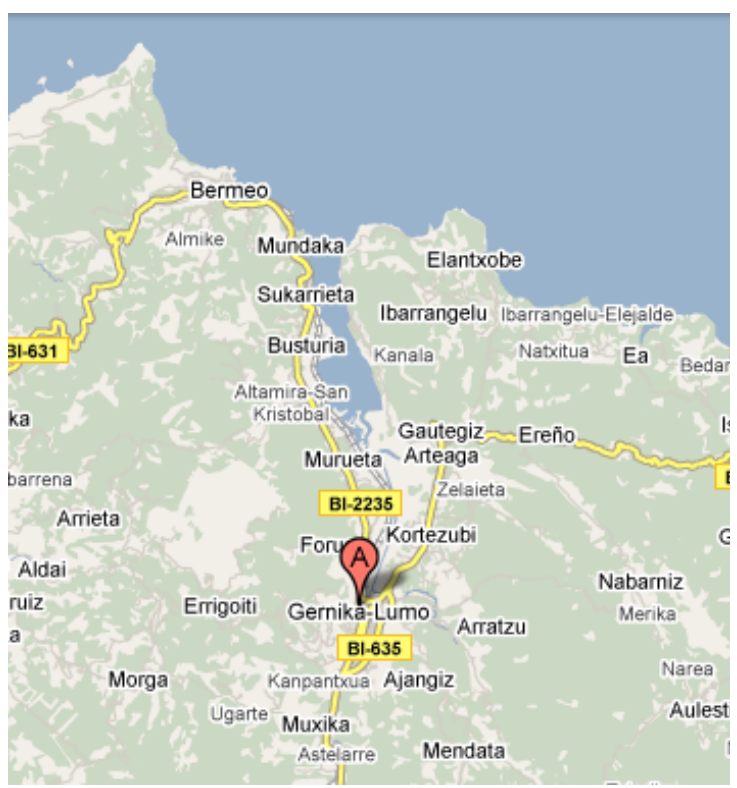

Map 2. Location of Gernika in the biosphere.

Nowadays Gernika is one of the biggest towns in the area and it has 16,500 inhabitants more or less. Unfortunately, only the $69.3 \%$ of the inhabitants know Basque and many of them only know the standard variant so it is not as easy as it seems to find appropriate informants. Nevertheless, Gernika has a strong Basque speaker community and those who come to Gernika also speak Basque when they interact with people from there.

By the way, it is important to point out the devastating bombing it suffered in 1937 because it made the population decrease drastically. The town was reconstructed 
from the ashes of the bombing but the survivors had to live for at least 4 years on the nearby towns. Afterwards not only did the previous inhabitants come to Gernika but also the inhabitants of those towns nearby, so there is no doubt that in those years different spoken Basque variants were in contact and interaction.

Moreover, as it can be expected, the standardization of Basque has influenced its spoken variants. We strongly believe that Standard Basque (promoted by Euskaltzaindia, the Academy of Basque in 1968), has a noticeable effect on the spoken language of the youngest generations, as it is widely present in the school system and the media.

\section{Theoretical framework}

Overall, in this research we have followed Labov's large investigations ([1994] 2010, [2001] 2010, 2010) and his disciples' conception and thinking (Peter Trudgill 1983; Ralph Fasold 1969; Lesley Milroy 1980, 1999; James Milroy 1992; Sali A. Tagliamonte 2012; Penelope Eckert 2000). According to these authors, language change cannot be understood out of its social context, as social pressure is always affecting to language. That social pressure generates linguistic differences in the community that show differentiation in social-factors.

Nowadays, it is universally accepted that internal-factors generate changes in the linguistic system but there are changes generated by external-factors too. Variationist Sociolinguistics investigates the variation that is systematic and intrinsic to language, both in the diachronic and the synchronic aspects, as the objective is to know how does the mechanism that links internal factors and external factors works (Sankoff 1988: 157).

On the other hand, neogramarian linguists (Mitxelena 1963) have defended the regularity of change: a phonic change happens in all contexts that it is possible, so change affects to all the words that content that sound or, at least, that sound in a specific context. At any rate, the solid bases of geographic dialectology have shown by the lexical isoglosses that the regularity of change is more complex than what it seems to be (apud Chambers \& Trudgill 1994: 62). In fact, changes are not given uniformly in 
language, so to achieve the regularity that neogramarians want language has to go through a fluctuating state previously.

Moreover, Sturtevant (1947: chap 8) divided 3 stages into the process of language change: initial stage, expansion stage and final stage. In the initial stage of the change, some different variants appear just in a reduced social group. In the expansion stage, the new variant spreads to a bigger group and due to the social interaction starts to battle with the initial variant. In the final stage, the weakest variant looses and the change achieves regularity. So, regularity of changes is just the last stage of an imbalance period. Elsewhere, before Labov's investigations, it was not taken into account the social aspect of languages and linguistic variables due to the fact that it was thought that feelings and thoughts about language were unreachable and extralinguistic (Bloch \& Trager 1942). But Labov proved that there are phonetic changes linked with social factors like age, social class, genre and ethnicity (Labov 1963: 74).

The patterns that have emerged from these undertakings have demonstrated that linguistic change is not only the result of universal principles but is also shaped by the social context in which it occurs.

However, heterogeneity is essential for the sociolinguistic view of the community, but that heterogeneity is orderly and that is not far from the view of the neogramarians. In fact, as Milroy \& Gordon (2003: 7) defend:

\footnotetext{
For variationists, not only is variation essential and intrinsic to human language, but the detail of systematic, socially embedded variable behavior is the key to an understanding of dynamics of language change.
}

Nowadays, it is thought that the data come from the recurrent choices speakers make in the course of production. In this way, each choice is viewed not simply as an instance or token of use, but as a choice made within the context of the grammar from which it comes. When a large body of repeating tokens is part of the analysis, the choices can be assessed statistically so as to uncover the meaningful patterns of use (Cedergren \& Sankoff 1974; Labov 1969; Poplack \& Tagliamonte 2001: 89). The choices 
are taken to represent the (underlying) variable grammar of the speaker as well as the grammar of the speech community to which she belongs (Tagliamonte 2012: 9):

Thus, this research is made from the sociolinguistic point of view, so instead of analyzing language generally, we have looked at some linguistic variables that show variation in a certain period of time and try to specify which is the social factor that generates the change.

\section{Methodology and corpus}

In order to study the interaction between linguistic variables and social factors and the influence that Standard Basque has in the spoken variant of Gernika, data for our research was collected with a questionnaire of 100 sentences to translate from Spanish into vernacular Basque. In all, our corpus consists of 63 people that have translated those 100 sentences. It is true that these kinds of questionnaires increase the risk of gathering formal styles but, on the other hand, the data obtained is very productive because, due to its accuracy, they are easy to compare.

All the recordings were made in a calm place and a relaxed atmosphere and with an Olympus VN-2.100 PC digital voice-recorder. Afterwards, the audio was analyzed with the Praat program. All the answers were transcribed with the IPA alphabet and introduced in a database in order to make graphics and interpret them. Those informants haven't been selected in a stratified way but randomly. At any rate, informants have been selected according to some profiles or social factors:

\subsection{Social factors}

In this research, we have studied the realizations of some linguistic variables taking into account these social factors such as age, genre, parent's origin and the school where they have studied. 
The independent variable of age has been divided into 5 main groups: 1) <1950, 2) $1951-1964,3) 1965-1980,4) 1981-1990$ and 5) 1991-2000. People from group 1) at school have only been educated in Spanish because of the Spanish Civil War (1919-1936) and the following Franco's dictatorship (1936-1972). Moreover, Basque was not standardized until 1968, so its influence did not reach this generation and they have only heard it on the media. People from group 2) had only Spanish education too at school, but most of them need to familiarize with Standard Basque later so as to suit their jobs. People from group 3) are the first ones that received education totally in Standard Basque at school, so they have been in contact with it since they started going to school and they are familiarized with it from the very early ages of childhood. People from group 4) had also received education in Standard Basque but we have considered important to separate this age-group due to the relationship with new technologies, that's it, people from this group not only are those who are in the way between teenagers and adults but they are also the ones who have suffered the change from a traditional society to a technological society. Finally, people from group 5) are teenagers and, as it is thought, this is the first stage of variation, when the child starts to reach maturity and so they distance themselves from their parents.

Since we thought it was important for our conclusions, we divided those from groups 4 and 5 also taking into account the school where they have studied. In fact, in Gernika we have one state school called Allende Salazar and three public schools called Seber Altube, San Fidel and Mertzede. This last one is the only one that offers education in Spanish so it is the school where most of the immigrants go to.

Apart from that, the variable of genre is divided into the two logical groups: males and females; and finally, as it is not as easy as it seems to find people who have both parents from Gernika, the variable of the parent's hometown has been divided into 3 groups: 1) those who have at least one parent from Gernika, 2) those who have both parents from towns near Gernika and 3) those who have not Basque parents.

On the other hand, as we have previously said, we have analyzed how some linguistic variables happen in each social factor, so we have researched the variants of the linguistic variables in each social factor. 


\subsection{Linguistic variables}

In this contribution, we analyze 5 linguistic variables which present an ongoing despalatalization: variable (is), variable (it), variable (il), variable (ind) and (ild) and variable (i_V). All the variables have been studied in all contexts, that is, between different consonants, between vowels and in coda.

(is) variable: it is known that in local dialect we do not differentiate between the apical sibilant [s] $(\langle\mathrm{s}\rangle)$ and [s] $(<\mathrm{z}>)$ laminal sibilant due to an ancient neutralization that took place in favor of the apical sibilant [s]. On the other hand, when in a word the sibilant is preceded by the back close vowel [i] or a palatal approximant [j], the sibilant is palatalized to []$](<x>)$, but this palatal variant is not accepted for Standard Basque:

$$
\begin{aligned}
& \text {. bisi > bixi 'life, to live' } \\
& \text {. gison> gixon 'man' } \\
& \text {. isen > ixen 'name' } \\
& \text {. aise > axe 'wind' } \\
& \text {. eleisa > elexa 'church' }
\end{aligned}
$$

(it) variable: when the back close vowel [i] or the palatal approximant [j] precedes a voiceless alveolar stop [t], in western varieties of Basque the stop is palatalized to different consonants: to a voiceless palatal plosive $[\mathrm{c}](<\mathrm{tt}\rangle)$ or to a voiceless palatealveolar affricate $[\mathrm{t}] \mathrm{f}(<\mathrm{tx}>)$. In Standard Basque, the palatalized variable is not accepted:

. aitita> aittitte, aitxitxe 'grandfather'

. ito> itto, itxo 'drown, choke'

. polita> politte, politxe 'nice'

. badakit> badakitt, badakitx 'I know it'

On the other hand, young use the $[\mathrm{ts}]<\mathrm{tz}>$ voiceless laminal affricate variant and the $[\mathrm{ts}]<$ ts $>$ voiceless apical affricate variant too.

(il) variable: When the back close vowel [i] or the palatal approximant [j] precedes an alveolar lateral approximant [I] the consonant is palatalized to the palatal lateral approximant $[\Lambda](<\|>)$ or to the palatal approximant $[j](<y>)$, but this last palatal variant 
is not accepted in Standard Basque. It is important to point out that in Spanish has happened the same change:

$$
\begin{aligned}
& \text {. pila> [pi/o], [pijo] ], 'a lot' } \\
& \text {. ilun> [i/un], [ijun], 'dark' } \\
& \text {. hilabete> [i/ie], [ijָie], 'month' } \\
& \text {. mailu> [maᄉu], [maj̦u], 'hammer' }
\end{aligned}
$$

(ind) and (ild) variables: When the back close vowel [i] or the palatal approximant [j] precedes a dental nasal [nd] or a dental lateral [ld] not only the following consonant is palatalized but also the voiced dental stop, so we will have sounds as [isili ${ }^{j} \mathrm{j}$ ] and [esinin ${ }^{j}$ fot], but this palatal variants are not accepted for Standard Basque:

. hilda> [ilje], 'died'

. isildu> [isiliju], 'shut up'

. indar> [injer], 'strength'

. eginda> $\left[e^{\mathrm{j}} \mathrm{n}_{\mathrm{j}}^{\mathrm{j} e}\right]$, 'done'

. ezin dut> [esininfot], 'I can not'

(i_V) variable: On the other hand, when in central varieties and Standard Basque we have a hiatus formed by a back close vowel [i] and any other vowel, in western varieties a sibilant consonant epenthesis is embedded between the two vowels. In most of the cases, that epenthesis is voiced [3] $(\langle x\rangle)$ but it can be voiceless too [s] $(\langle s\rangle)$. In any case, Standard Basque doesn't have any epenthetic consonant in this case:

$$
\begin{aligned}
& \text {. bihotz> [bizots] ], [bișotș], 'heart' } \\
& \text {. indiaba> [in jizaßa], [indișaßa], 'bean' } \\
& \text {. ogia> [oyize], [oyișe], 'bread' } \\
& \text {. merienda> [merizendie], [merisendie], } \\
& \text {. armarioa> [armarizoa], [armariš }
\end{aligned}
$$

\section{Analysis}

On the one hand, our data shows that, as we had expected, the most significant social-factor for variation is age since all linguistic variables show age leveling. 
Regarding (is) variable, the youngest generation's data show that the palatal variant that is dominant in adult generations (in lines) is fading away and the apical sibilant (in white) has taken its place:

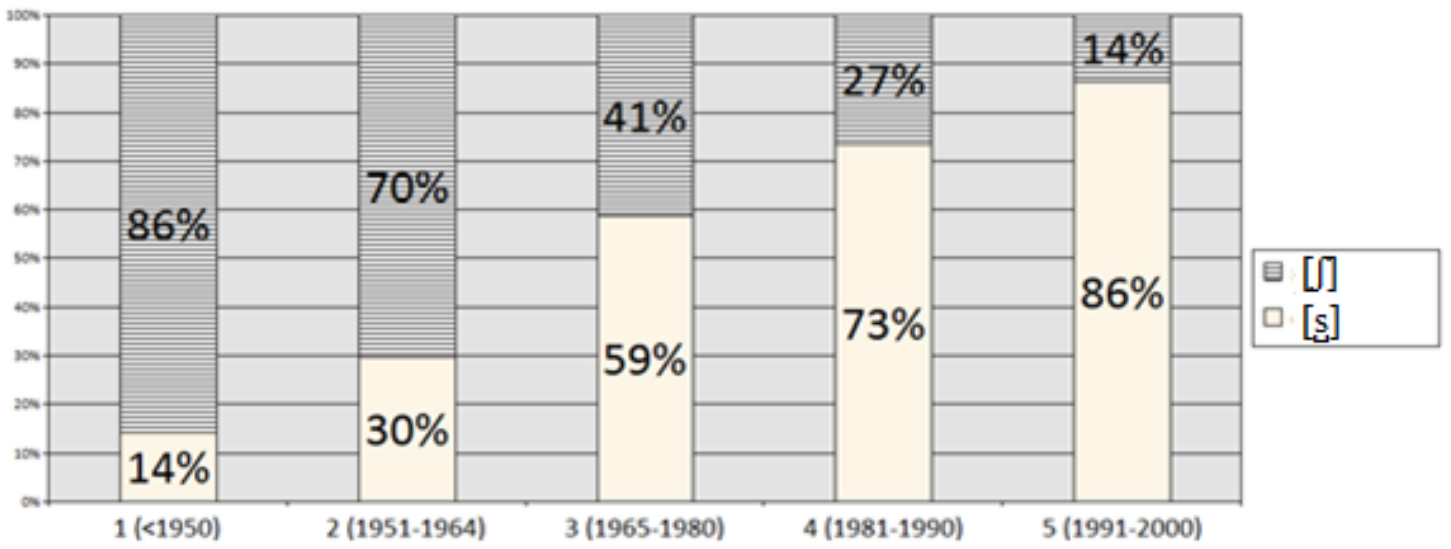

Graphic 1. (is) variable according to age groups.

According to the epenthesis between vowels, in the two oldest age-groups the only sound used is the voiced palate-alveolar fricative (grey dots), whereas in the youngest age-group the most used one is the voiceless apical sibilant (white). On the other hand, in the second youngest age-group it can be seen that Standard Basque has started to influence, as there are appearing forms without any epenthesis (rhombuses); forms that increase in the youngest age-group indeed:

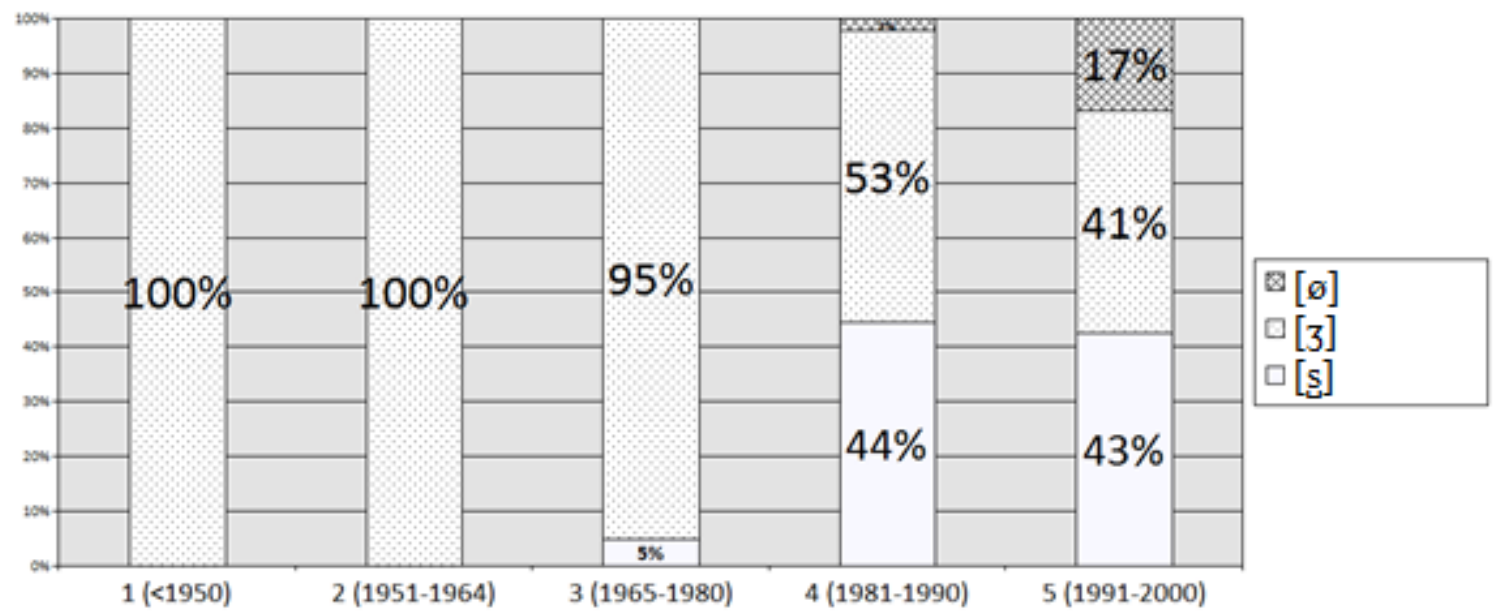

Graphic 2. (i_V) variable according to age groups. 
In the case of (it) variable, the dominant variant in the oldest age-groups is voiceless palatal plosive (grey rhombuses), which in the youngest generations is about to disappear. In the youngest generations other variants have taken its place, which sometimes is the palate-alveolar affricate (dark grey), other times the palato-laminal affricate (white), and other times the palate-apical affricate (dots). As we can see in the graphic, the non-palatalized variable is spreading as age decreases, most probably due to the fact that in Standard Basque the palatalized forms are not accepted:

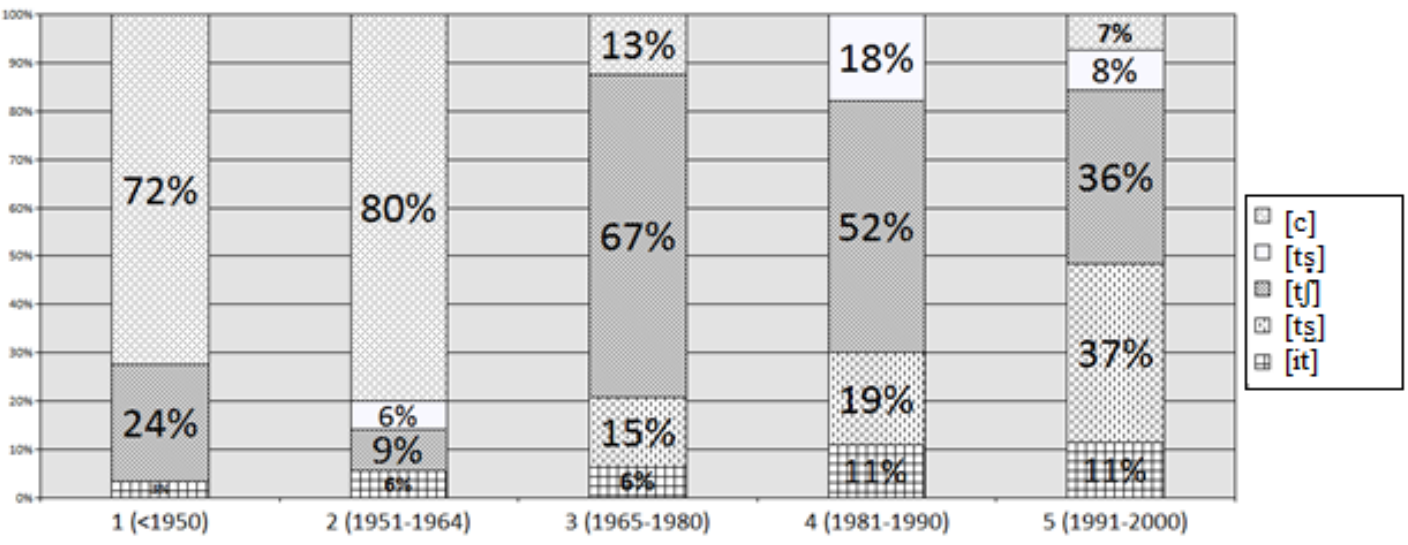

Graphic 3. (it) variable according to age groups.

In the case of the (il) variable we can also see that whereas in the oldest age-group the only variant is the palatal lateral approximant (white) and the dominant one in the $2^{\text {nd }}$ age-group, in the next age-groups the dominant variant is the palatal approximant (dots) and in the youngest age-groups the palatal lateral approximant variant is about to disappear. It can be highlighted that in many languages in contact, such as Spanish, the same change has occur so the change in our speech can be due to the influence of Spanish: 


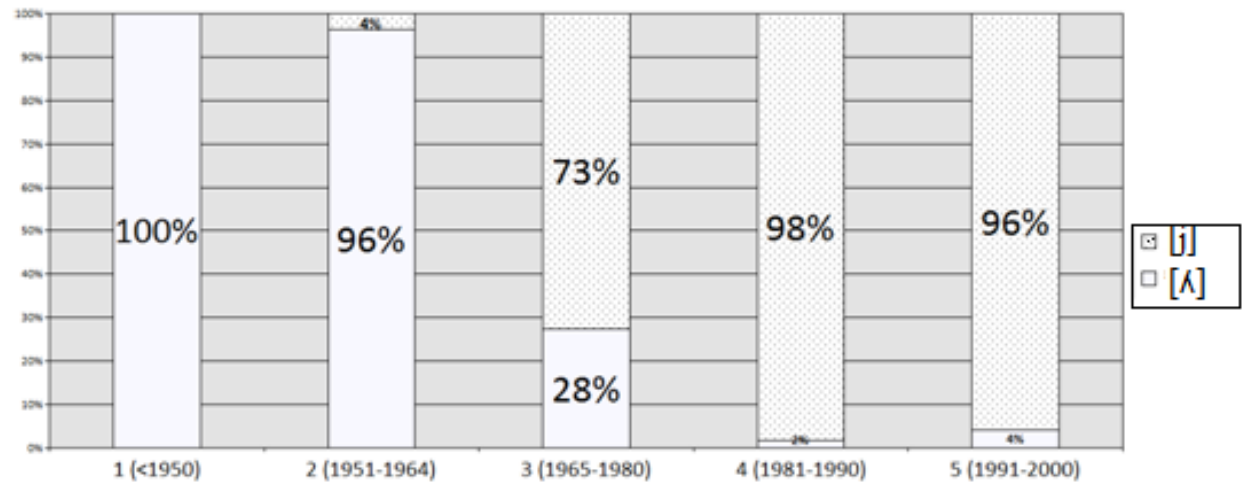

Graphic 4. (il) variable according to age groups.

Finally, (ind) and (ild) variables are generally palatalized (white) in the oldest agegroups but in youngest generations the habit to palatalize them is decreasing, surely, due to the fact that in Standard Basque the palatalized form is not accepted:

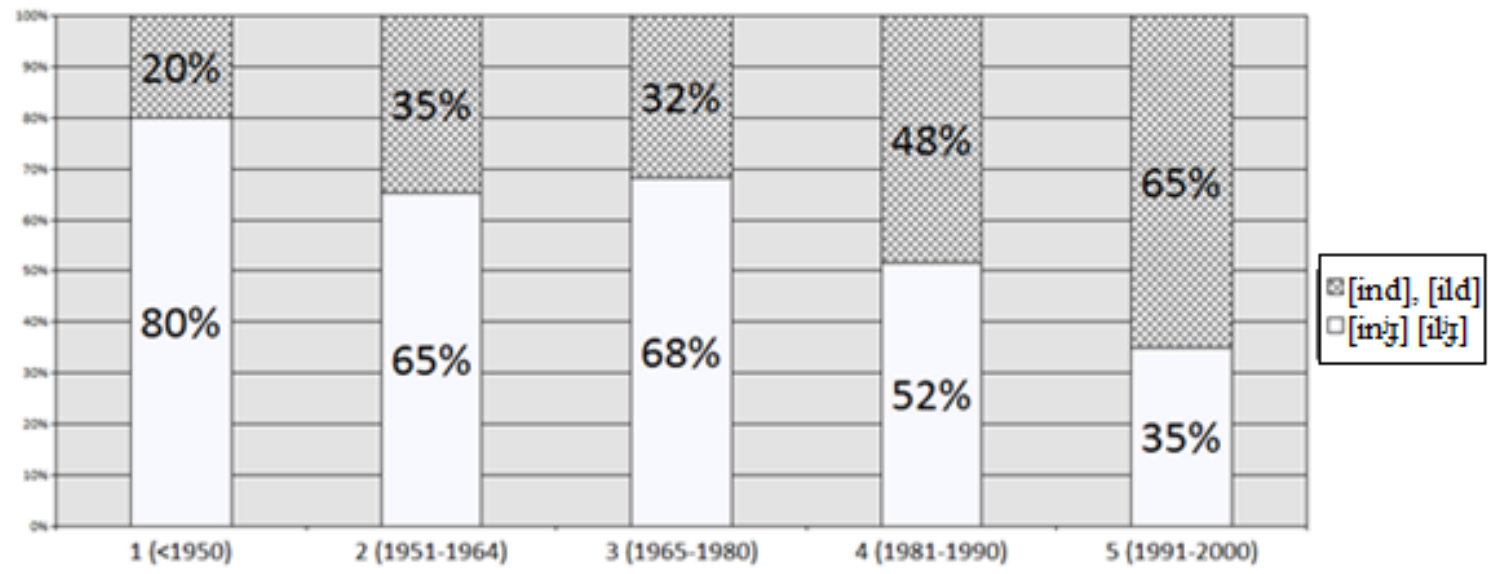

Graphic 5. (ind) and (ild) variable according to age groups.

On the other hand, data gathered in this research show that genre is also an important social-factor for variation. In fact, in all linguistic variables men seem to be more conservative than women: women from the $3^{\text {rd }}$ age-group seem to be the engine of the change as the voiceless variable appears here firstly (white). In the $4^{\text {th }}$ and $5^{\text {th }}$ agegroups men seem to have conserved better the voiced variable of the epenthesis (dots): 


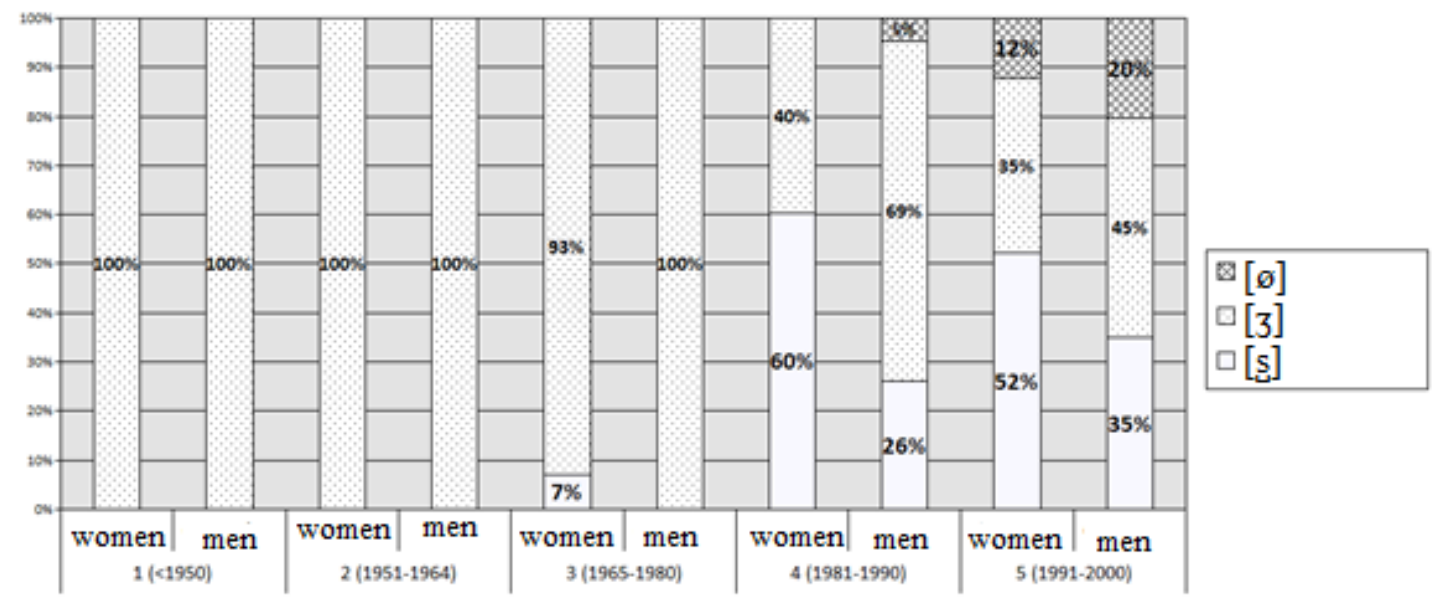

Graphic 6. (i_V) variable according to genre and age groups.

In (it) variable it can also be seen that men have conserved better the voiceless palatal plosive variant (rhombuses) since in the $3^{\text {rd }}$ age-group of women that variant is already lost:

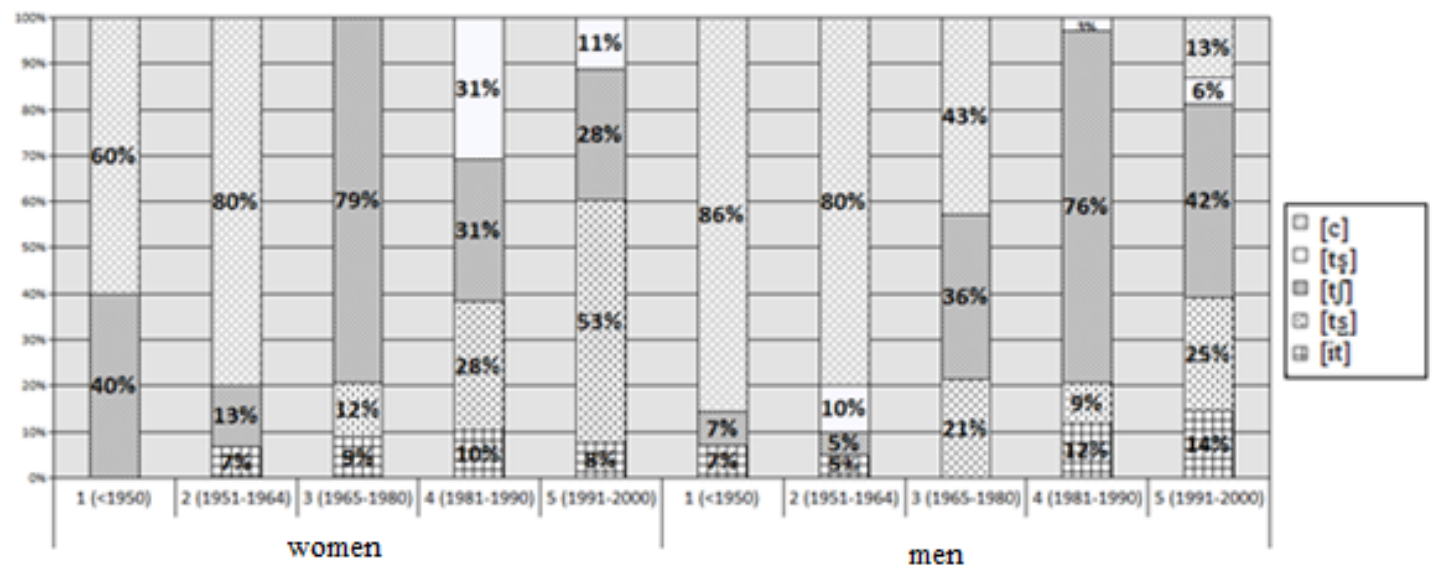

Graphic 7. (it) variable according to genre and age groups.

In (is) variable we can see the same too: men have conserved better than women the palatal sibilant approximant variant of (is) variable (lines): 


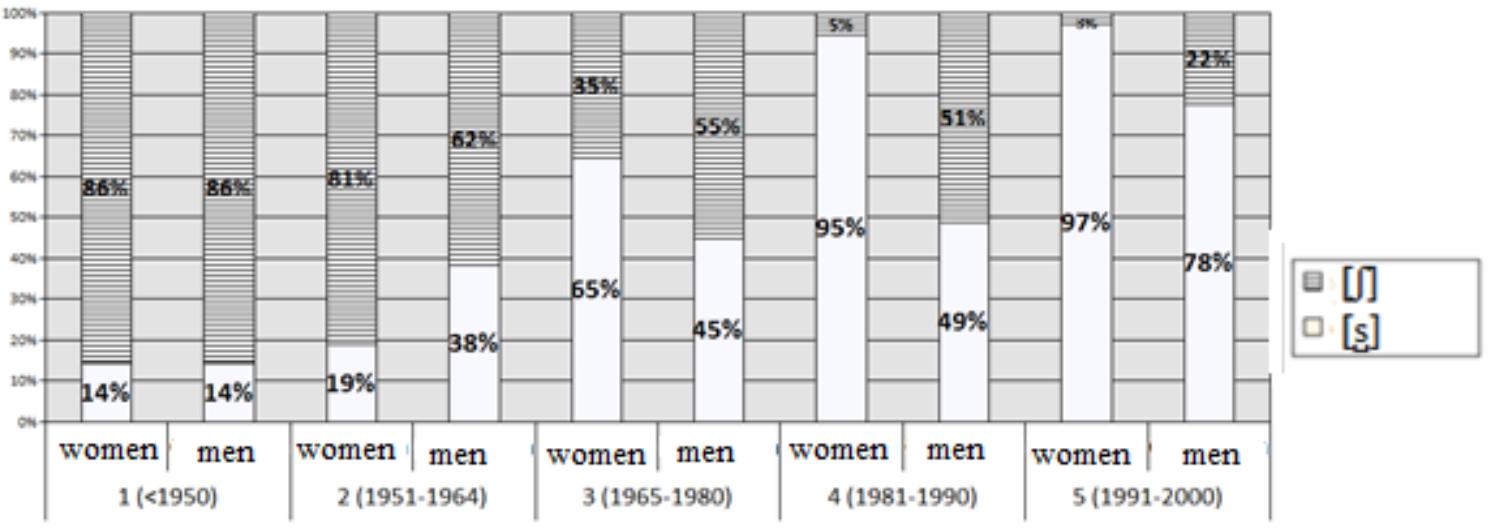

Graphic 8. (iz) variable according to genre and age group.

And in variable (ind), (ild) we can see that women have an ongoing tendency to not palatalize (rhombuses) the consonants after vowel $i$ :

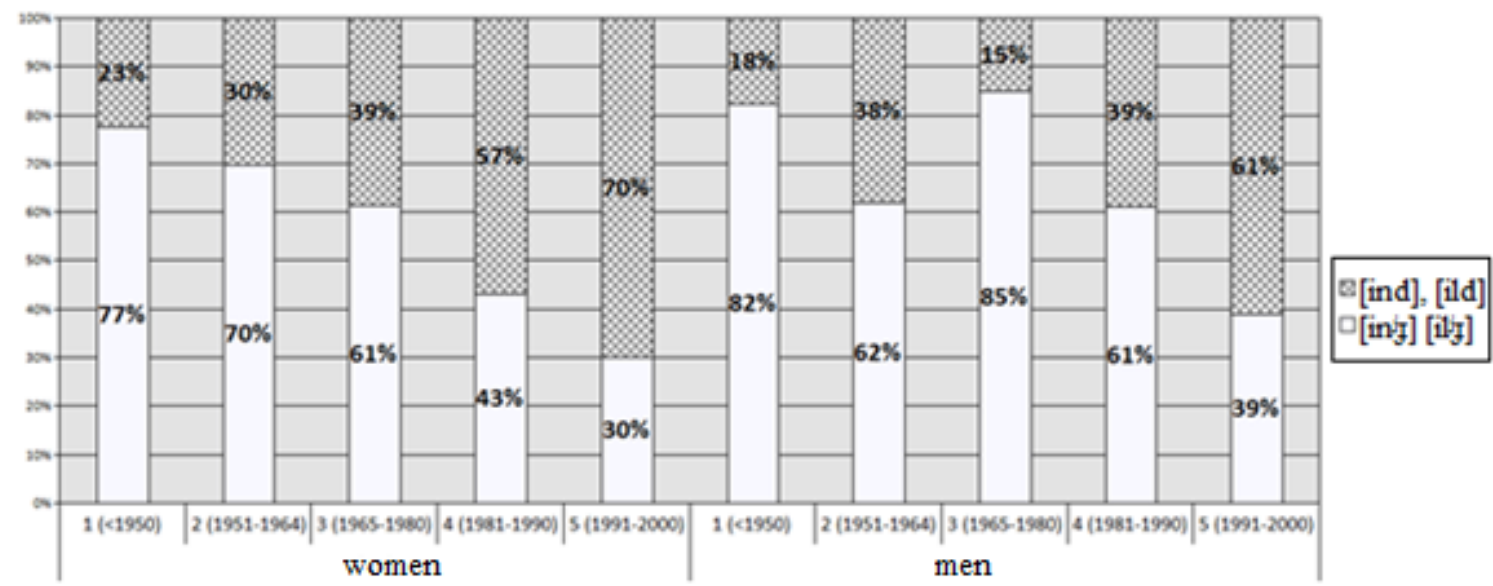

Graphic 9. (ind) and (ild) variable according to genre and age group.

In addition, out data show that differentiation between schools is important too, but there is not any school that it is totally innovative or totally conservative in all linguistic variables. In fact, some schools seem to be conservative in some linguistic variables but innovative in others, and vice versa. That's why we are not going into that today.

Finally, parent's language model seems to have importance too in some linguistic variables. For example, in (it) variable those who have Spanish parents do not use the voiceless palatal plosive variant (light rhombuses). 


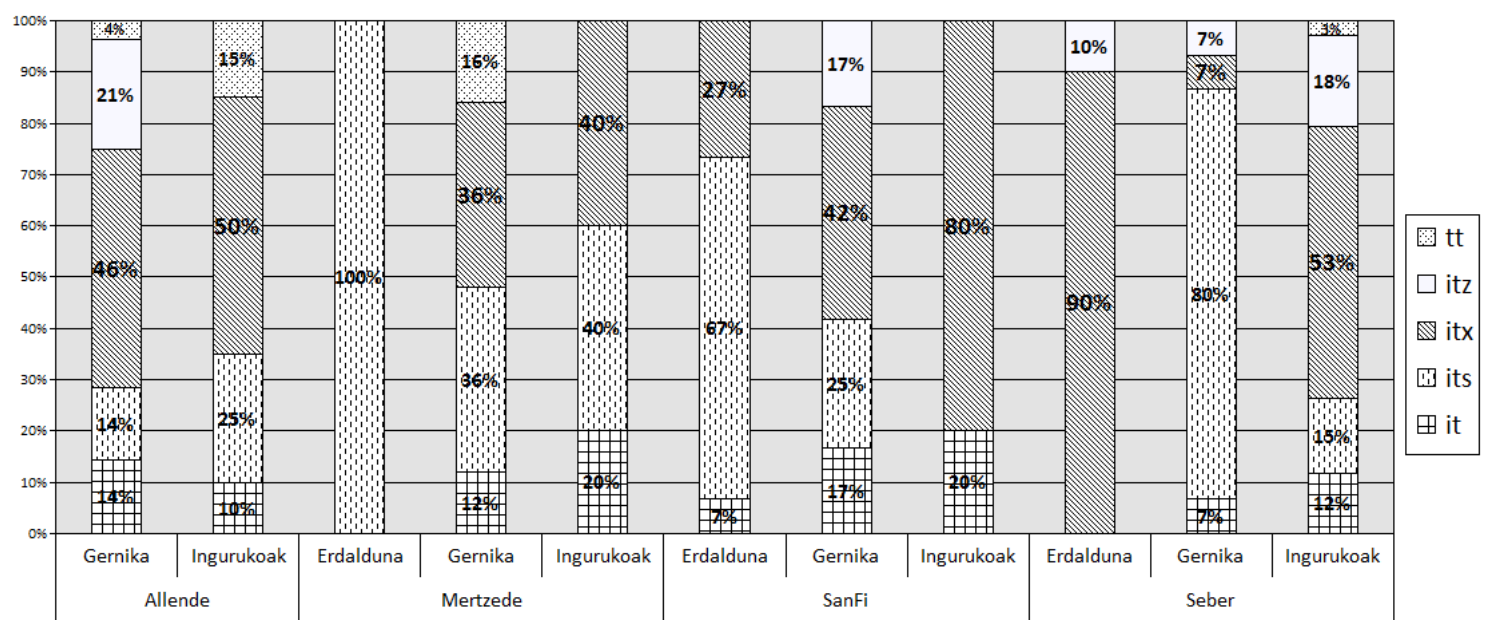

Graphic 10. (it) variable according to schools and parent's language.

\section{Conclusions}

The major conclusion to be drawn is that both fricative and affricate sibilants are undergoing a despalatalization in the vernacular Basque of Gernika because while adults use palatal variants, young use non-palatal ones. That's why, it can be concluded that the vowel [i] or the palatal approximant [j] are losing their capacity to palatalize the following consonants. As we had expected, this has to see with the variants that are not accepted in Standard Basque, as children pick samples from their environment and, if in school the palatalized forms are rejected, children do reject them from their day to day speech too.

On the other hand, (it) variable's variants show that in Gernika the affricate consonants have been neutralized by the young generations, because whereas adults use the palatal plosive variant, young use the palate-alveolar affricate, the palatolaminal or the palate-apical variable alternatively. Thus, whereas adults make difference between kortxo, atzo and aittitte, young pronounce them with the same sound. Therefore, it can be said that the phonological inventory of adults and the young is not the same. However, it seems that the change is progressive, as the palatal plosive pronounced by adults in Gernika has more noise than in other Basque vernacular varieties, so the variant of Gernika is closer to the features of an affricate. 
Fricatives have also undergone a desphonologization, as youngest generations do not make any distinction between palatal and apical. Additionally, also (il) variable has undergone a desphonologization, as youngest generations have lost the palatal lateral approximant variant. Thus, whereas adults make difference between [i/ie] 'hile', [oje] 'ohe' eta [zat] 'zait' youngest generations don't: [ijijie] 'hile', [oj̦e] 'ohe' eta [j్jat] 'zait'.

On the other hand, data gathered in this research show that genre is also an important social-factor for variation. In fact, in all linguistic variables men seem to be more conservative than women and, moreover, women from the $3^{\text {rd }}$ age-group seem to be the engine of linguistic changes.

\section{References}

AMORRORTU, E. (2003) "Hizkuntza aldakortasuna eta identitatea", in I. Gaminde, J. L. Goikoetxea \& I. Sarriugarte (eds.), Ahozkotasuna aztergai, Bilbao: Mendebalde Kultura Alkartea, 157167.

AURREKOETXEA, G. (1995) Bizkaieraren egituraketa geolinguistikoa, Leioa: UPV-EHUko Argitarapen Zerbitzua/Serie Tesis doctorales.

AURREKoetXEA, G. (2008) “Bariazio soziolinguistikoa Dimako euskaran”, Euskalingua, 12, 17-26.

Bloch, B. \& G. L. Trager (1942) "Outline of linguistic analysis", LSA Special Publication, Washington, D.C.: Linguistic Society of America.

CAmINo, I. (2003) Hego Nafarrera, Iruña: Nafarroako Gobernua.

CAMPBELL, L. (1988) Historical Linguistics: an Introduction, Reed. [2004], Edinburgh: Edinburgh University Press, and Cambridge, MA: MIT Press.

Cedergren, H. \& D. L. SANKoff (1974) "Variable rules: performance as a statistical reflection of competence", Language, 50, 333-55.

Chambers, J. K. \& P. TRUdgilll (1994) La Dialectología, Madrid: Visor Libros.

ECKERT, P. (2000) Linguistic variation as social practice, Malden Mass: Blackwell.

ENSUNZA, A. (2014) "Gernika-Lumoko euskararen aldakortasuna: aldagai fonetiko zenbait", Anuario de Seminario de Filología Vasca "Julio de Urquijo" (to be printed).

EzenarRo, A. (2008) "Etxebarria eta Bolibarko bariazio soziolinguistikoa" [Linguistic Variation in Etxebarria and Bolibar], Uztaro, 67, 59-84. 
Dialectologia 16 (2016), 71-91.

ISSN: 2013-2247

FASOLD, R. W. (1969) A sociolinguistic study of the pronunciation of three vowels in Detroit speech, Georgetown University mimeograph.

Gaminde, I. (1984a) Aditza Bizkaieraz, Tomo I, Iruñea: Udako Euskal Unibertsitatea.

GamInDE, I. (1984b) Aditza Bizkaieraz, Tomo II, Iruñea: Udako Euskal Unibertsitatea.

GamINDE, I. (1985) Aditza Bizkaieraz, Tomo III, Iruñea: Udako Euskal Unibertsitatea.

GAMINDE, I. (2003) "Mungialdeko herskarien eta afrikatuen txandaketaz", Euskalingua, 2: 10-17.

GAMINDE, I. (2009) "Hiztunen generoaren eta adinaren pertzepzioaz", Revista de sociolingüística $B A T, 71,151-164$.

GAMINDE, I. (2010a) Bizkaiko gazteen prosodiaz: euskaraz eta gaztelaniaz, Bilbao: Mendebalde Kultur Alkartea / Bizkaiko Foru Aldundia.

GAMINDE, I. (2010b) "Bilboko gazte euskaldunen ezaugarri linguistikoez", in Mendebalde Kultura Alkartea: Bilbon Mundua Ikusi, 35-59.

GAMINDE, I. \& A. ROMERo (2011) "Generoa eta adina Bermeoko berbaldiaren fonemen eta hotsen frekuentzian", Fontes Linguae Vasconum, 113, 115-138.

Gaminde, I., A. Romero \& H. LegarRa (2012) Gramatika eta hizkuntza bariazioa Bermeon, Bermeo: Bermeoko Udala.

GAMINDE, I. \& ZUBillagA, H. (2010) "/t/ ren palatalizazioa Lekeitioko euskaran", Ikastorratza, 3, $1-9$.

GARMENDIA, L. (2008) “Hizkuntza aldakortasuna Zaldibiako euskaran: ikuspegi soziolinguistikoa", in Euskalgintza XXI. mendeari buruz. Euskaltzaindiaren nazioarteko XV. Biltzarra, 2001, Bilbao: Euskaltzaindia, 1-2.

LABOV, W. (1963) "The social motivation of a sound change", Word, 19, 273-309.

LABOV, W. (1966) The social stratification of English in New York City, Washington, D.C.: Center for Applied Linguistics.

LABOV, W. (1969) "Contraction, deletion, and inherent variability of the English copula", Language, 45 (4), 715-762.

LABOV, W. (1972a) Language in the Inner City, Philadelphia: University of Pennsylvania Press.

LABOV, W. (1972b) Sociolinguistic Patterns, Philadelphia: University of Pennsylvania Press. [1983], Modelos sociolingüisticos, Madrid: Cátedra.]

LABOV, W. (1981) "What can be inferred about change in progress from synchronic descriptions?", in D. Sankoff \& H. Cedergren (eds.), Variation Omnibus [NWAVE VIII]. Alberta: Linguistic Research, 177-200. 
LABOV, W. (1994) Principles of Linguistic change. Volume 1: Internal factors, Reed. [2010], Oxford: Blackwell.

LABOV, W. (2001) Principles of Linguistic change. Volume 2: Social factors, Reed. [2010], Oxford: Blackwell.

LABOV, W. (2010) Principles of Linguistic change. Volume 3: Cognitive and Cultural factors, Oxford: Blackwell.

LUJANBIO, O. (2011) Hizkuntza-aldakortasuna Goizuetako euskaran, Bilbo: Eusko Ikaskuntza.

MAKAZAGA, J. M. (2010) Elgoibarko Ahozko Euskara, IKER-25, Bilbao: Euskaltzaindia \& UPV-EHU.

MILROY, J. (1992) Linguistic Variation \& Change, Oxford: Blackwell.

MILROY, L. (1980) Language and Social Networks, Reed. [1987], Oxford: Basil Blackwell.

MILROY, L. (1999) Language ideologies and linguistic change: towards an interpretation, Oxford: Blackwell.

MILROY, L. \& M. GORDON (2003) Sociolinguistics. Method and interpretation, Oxford: Blackwell.

MitXelenA, K. (1963) Lenguas y protolenguas, Reed. [1990], Suplementos del Anuario de Seminario de Filología Vasca "Julio de Urquijo", Donostia.

MitXelenA, K. (1981) "Lengua común y dialectos vascos", Anuario de Seminario de Filología Vasca "Julio de Urquijo", 15, 289-313. Reed. [2011], in Anuario de Seminario de Filología Vasca "Julio de Urquijo". Luis Michelena. Obras Completas, VII, Donostia \& Gasteiz: UPV-EHU.

ORMAETXEA, J. L. (2002) Aramaioko euskara, Aramaio: Aramaioko Udala.

ORMAETXEA (2011) "Otxandioko hizkera: adinaren araberako bariazioa", Fontes Linguae Vasconum, 108, 249-262.

Poplack, S. \& S. A. TAGLIAMONTE, (2001) African American English in the Diaspora: Tense and Aspect, Malden: Blackwell

SANKOFF, D. (1988) "Sociolinguistics and syntactic variation", in F. J. Newmeyer (ed.), Linguistics: The Cambridge Survey, Cambridge: Cambridge University Press, 140-161.

SANTAZILIA, E. (2010) “Luzaideko hizkuntz bariazioa”, Fontes Linguae Vasconum, 111, 219-248.

StURTEVANT, E. (1947) An introduction to linguistic science, New Haven: Yale University Press.

TAgliamonte, S. A. (2012) Variationist Sociolinguistics. Change, Observation, Interpretation, Oxford: Blackwell.

TRASK, R. L. \& R. M. MILLAR (2007²) Trask's Historical Linguistics, London: Hodder Arnold.

TRUDGILL, P. (1983) Sociolinguistics, Harmondsworth: Penguin.

UNAMUNO, L. (2010) “Adinaren araberako bariazioa Gizaburuagako hizkeran”, Euskalingua, 1641-48. 
Dialectologia 16 (2016), 71-91.

ISSN: 2013-2247

ZelAIETA, E. (2008) Baztan-Bidasoako hizkeren azterkera dialektologikoa, Bilbao: Nafarroako Gobernua / Euskaltzaindia.

ZuAZO, K. (1998) “Euskalkiak, gaur”, Fontes Linguae Vasconum, 78, 191-233.

ZUAZO, K. (2003) Euskalkiak. Herriaren lekukoak, Donostia: Elkar.

ZuAZO, K. (2008) Euskalkiak. Euskararen dialektoak, Donostia: Elkar 